\title{
Decoding Sense in Caricatures: A Study in Semio-stylistics
}

\author{
Hasan Mohammed Saleh Jaashan \\ King Khalid University, Saudi Arabia; \\ Sanaa University, Yemen
}

\begin{abstract}
Icon, index, and symbol are the trichotomy parts of sign proposed by Peirce. The relationship between sign and object in them generates more and different interpretants. These parts focus primarily on non-verbal communication. Part of that nonverbal genre is caricaturing. Caricatures draw the attention of readers because caricaturists concretize the intended meaning in an overstatement style of drawing. This paper seeks to investigate how Peirce's terms of the sign; icon, index, and symbol are integrated into each caricature to complement the intended meaning of the caricaturists. Stylistically, it asks what are the foregrounding and de-familiarization features of these caricatures? It concludes that caricatures are mere connection between signs and objects results in formulating specific perception about the highlighted phenomena. Moreover, in caricatures there are some idiosyncratic aspects that make them de-familiarized and foregrounded. The researcher collected samples of caricatures from different newspapers to support his arguments.
\end{abstract}

Index Terms - caricature, semiotics, sign, foregrounding, de-familiarization, index, icon, symbol

\section{LITERATURE REVIEW}

\section{A. Semoitics}

The relationship between sign and meaning is the main subject matter of semiotics. As a field of Applied Linguistics, any verbal or nonverbal sign that communicates a message is dealt with within semiotics. In his first account about semiotics and sign, Peirce (1867-8) gives three inter-related elements for the sign; the first is the sign, the second is the object, and the third is the interpretant. Sign is the form of sign or the thing that refers to something/ object. Of course, not the whole sign refers to an object but only some parts of the sign refer to it. Peirce calls it "sign-vehicle" (Zalta, 2010). Objects are the concern matter of a sign. Similarly, not every feature of the object is relevant to sign. Only certain parts of an object make sign signifies it (ibid). The interpretant is the idea or the sense constructed in the mind about sign/object relation (Lalor, 1997). For Peirce, an interpretant is central to the content of sign because it focuses on how users interpret sign. Therefore, sign comes in different forms. Whatever has a meaning or communicates a message or anything that represents something is called sign (Atkin, 2005, Farias and Queiroz, 2003). Simply, the relation between sign, object and interpretant is the wide gate of senses that interpret the meaning conveyed by them. Beyond the verbal meaning, Barthes (1972) in his theory of the sign, mainly focuses on non-verbal communication and how it conveys connotative meanings. Photographs, paintings, smells, tastes, and touches are non-verbal signs and they obviously communicate messages. Peirce (1867) said that the interpretant can be presented in one of the three potential ways as a result of the sign/object relationship; icon, index, and symbol. All these three carry the same meaning and refer to the sign/object relationship to generate further interpretants (Zalta, 2010). They have different usages and are the core of studies in the field of semiotics. The first one icon represents a physical resemblance between sign and its object. The paradigm for that is a photo, which resolves the real person. It is a direct imitation of the object. Therefore, the photo of someone is the icon of him. The second one is an index that gives a clear evidence of what is being represented. The sign cannot exist without the presence of an object. For example, smoke is an index of fire and footprints are index of the foot. i.e., hence there is no smoke without fire. This connection is innately known and instilled in our brain. The third part of the sign is the symbol. It refers to cultural or conventional relation between sign and object (Müller $1994 \&$ Atkin 2005).

\section{B. Foregrounding and De-automatization}

In stylistics, foregrounding is twined with features beyond the language norms. It is against the background of the ordinary language. Leech (1969) adeptly observes that if anyone wants to investigate the value of a piece of artwork, he must focus on the components of interest and surprise, rather than on the automatic pattern. Such deviations from socially accepted norms are called 'foregrounding'. Foregrounding is utilized to de-automatize or de-familiarize the language of literature. It is noted when literary writers use unexpected regularity (parallelism) or unexpected irregularity (deviation) in a particular context to make linguistic items, symbols, or images stand out from the other surrounding context, images or text as passionate simulacra that represent existential paradigms (Walles, 2001, Leech \& Short, 2007). De-familiarization is another stylistic device used to present to readers the common things/ideas in an unfamiliar 
way in order to enhance their perception of the familiar things (ibid).

These two stylistic tools are not only suited to the analysis of literary texts but also to the scrutiny of the language of different disciplines. McIntyre (2003) assumed that foregrounding theory proffers an essential medium and powerful devices of presentation and analysis in stylistics. It might be employed not only in the analysis of texts but also as a methodology in teaching stylistic analysis. McIntyre thus suggests that when "de-familiarizing a work of art or a text we make it stand out from the norm - it becomes foregrounded " (McIntyre, 2003), and hence, the two theories of foregrounding and de-familiarization are deemed to be intertwined. Later, Jeffries and McIntyre (2010, p.3) maintain, "Stylistics draws upon theories and models from other fields more frequently than it develops its own unique theories. This is because it is at a point of confluence of many sub-disciplines of linguistics, and other disciplines but not seeking to duplicate or replace them". Some authors have applied the theory of foregrounding to the language of advertising (e.g., Bassey Ufot 2017).

\section{Caricatures}

Semiotics, as mentioned above, focuses on non-verbal communication (signs). Caricatures are one of those genres that communicate ideas with exaggeration and in an abnormal way. They contain some peculiar styles for communication. The caricaturist uses his unique/ idiosyncratic style to present the familiar ideas in an unfamiliar way to increase audience perception of the targeted phenomena. Caricature is originally an Italian word which means to load or exaggerate (Lynch, 1926). It is a regular style of communication in media. It occupies a vast space in almost all newspapers and magazines worldwide. Caricatures are simple hand-drawings that show the features of their objects in a style of overstatement and sarcasm. Caricatures are paintings/drawings (sign) and are intended to convey ideas, themes, and concepts (interpretant) which cannot be easily conveyed through texting. Chalániová (2011:7) said: "I am of the opinion that in the present-day fast commercial society, political cartoons are more easily 'digested' by the public than a page-long expert opinion, simply because they can be 'consumed' within seconds". The message behind caricatures is to inform, educate, amuse, publicize information in a funny way. It records the events of life in a memorable way and discusses some domestic issues in a comical style of speaking. The caricaturists reflect on society. They watch the performance of the power and bring to the surface the officials' cons (Sandbrook, 2010 \& Morris, 1992). Bakhtin (1990) says that a painted portrait gives us another person's point of view about something. A picture, just like a literary work of art (sign), consists of an object (a referent) and a perspective taken towards it (interpretant). Caricaturists commonly have big ideas. They use caricatures to convey the maximum intended message to the audience with minimal effort. The readers easily grasp the intended idea with its different layers of meaning at first glance to the caricatures. Caricatures may also be used as signs and as such fall within the purview of study. Caricaturists tend to over-emphasize some features of the object. For example, they show famous people with enormous nose, teeth, lips or ears to let the readers concretize the idea behind such exaggeration. Press (1981: p.77) indicates that "caricatures are low satire, ridiculing individuals and parties". Indeed, caricatures communicate messages from real life to the recipient (Cahn, 1984). As an art, it has a great power to zoom in and criticize social and political issues in society (Edward 1997, Feldman, 1995). These caricatures are either political, educational or economic.

\section{Data Analysis}

\section{A. Political Caricatures}

Political caricature conveys a political message to both politicians and readers alike. A caricaturist draws some features of politicians in an exaggerated style to zoom in what they do in their profession. Semiotically, Pierce's trichotomy analysis of the sign/object relationship can be noticed in all caricatures. For example, the physical appearances of the characters in a caricature refer to the real objects. This is an iconic relation between the sign and the object. Viewed as an index, political events and the behavior of politicians are the causes of drawing these caricatures. The case being thus, caricatures are the results of real political behaviors. Finally, when seen as a symbol, the way the caricatures are drawn and the features that are exaggerated are conventionally praised or belittled by the people who share political, economic, and cultural conditions in the targeted society (Greenberg 2002, Hansen, 2011). The caricatures under study here are samples out of many ones collected. Moreover, the foregrounding and defamiliarization elements of the caricatures will be brought into focus in order to enhance the semio-stylistic sense in these caricatures.

A) 


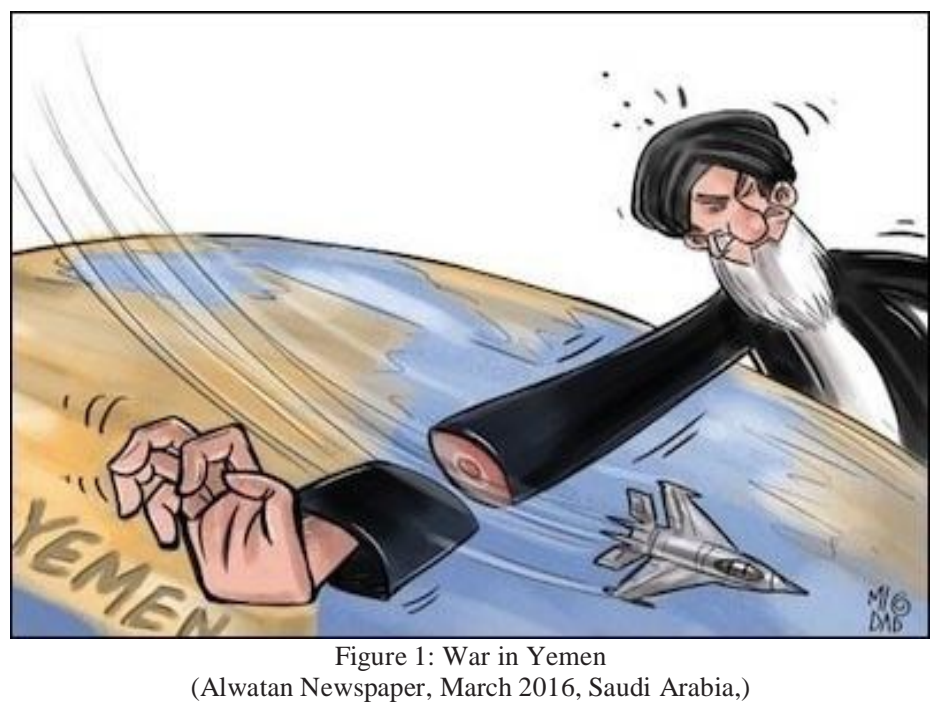

This caricature refers to the enmity between Iran and some Arab countries. The former interferes ideologically in the affairs of some Arab countries through their local fans. Yemen is one of them. The Arab coalition launched the military crackdown called "Storm of Determination" against Iran and its allies in Yemen.

The trichotomy parts of the sign are shown in this caricature. First, some elements of the caricature; a man with his turban and attire (sign) represents the leader of The Iranian Islamic Revolution (object). The relation between them is iconic because the person in the caricature resembles the Sheaa spiritual leader. Second, interference of Iran in Yemen (sign) is the reason behind cutting its hand (object) by the Arab Coalition Forces. Therefore, the elements of the caricature; the drone and the cut hand are the result of interference. This relation between the reason (sign) and the effect (object) is the index. Third, the perspective of some Arabs about Iran is negative because of the skeptic and ruining role it plays in the region. This view is conventional and might be changed if Iran changes its policy in the region. So, the relation between the skeptic role of Iran (sign) and the Arab perspective (object) is symbolic. This relationship between parts of the sign and part of the object in the caricature creates unsatisfying stance among Arabs about Iran (interpretant). This perspective is eligible for change if reverse policy from Iran is adopted.

B)

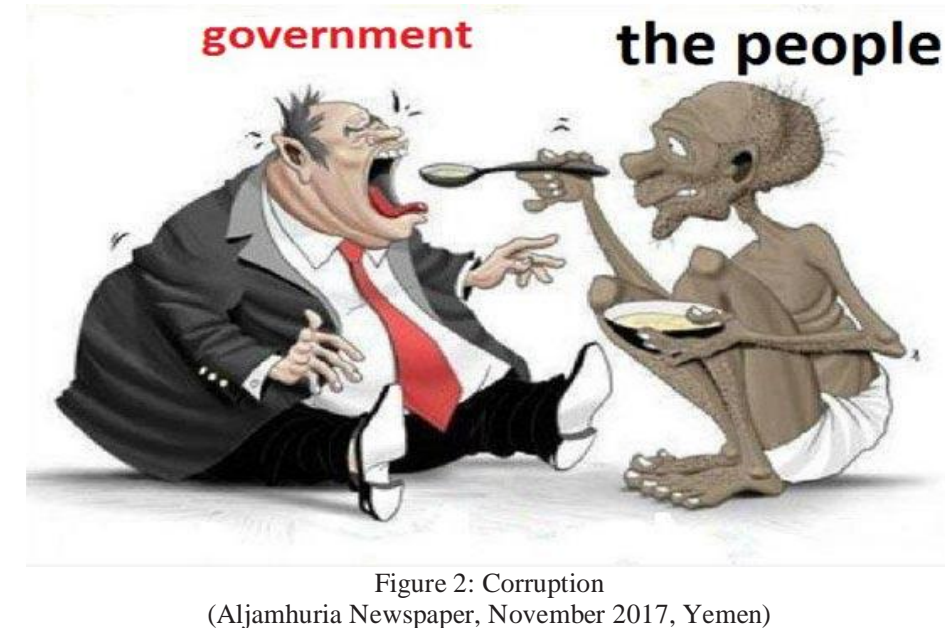

The relation between a corrupt regime and its people is depicted clearly in this caricature. The caricaturist shows the horrible situation people live in corruption. Whatever the people sock away, they pay it to the government as taxes. The basics for life are not available for people. On the other hand, the corrupt in the power lead a luxurious life.

The almost naked and skinny person in the caricature resembles the poor person in reality. The obese one refers to the corrupt government. The abstract relationship between some elements of the caricature (sign) and the real people (object) is iconic. The massive and unfair taxes the poor people pay to the corrupt government results in a big gap in society. The majority of the people suffer and the corrupt become rich and wealthy. This relation is an index. Finally, in the corrupt regime, it is conventional that the majority of the population suffer and live in poverty. However, only a few people live in luxury (interpretant). This means the former is common people who pay the heavy taxes and the latter is the government which does not care about them. This relation is symbolic. If the government changes its policy and care about the poor, this traditional view about it might be more positive. 
C)

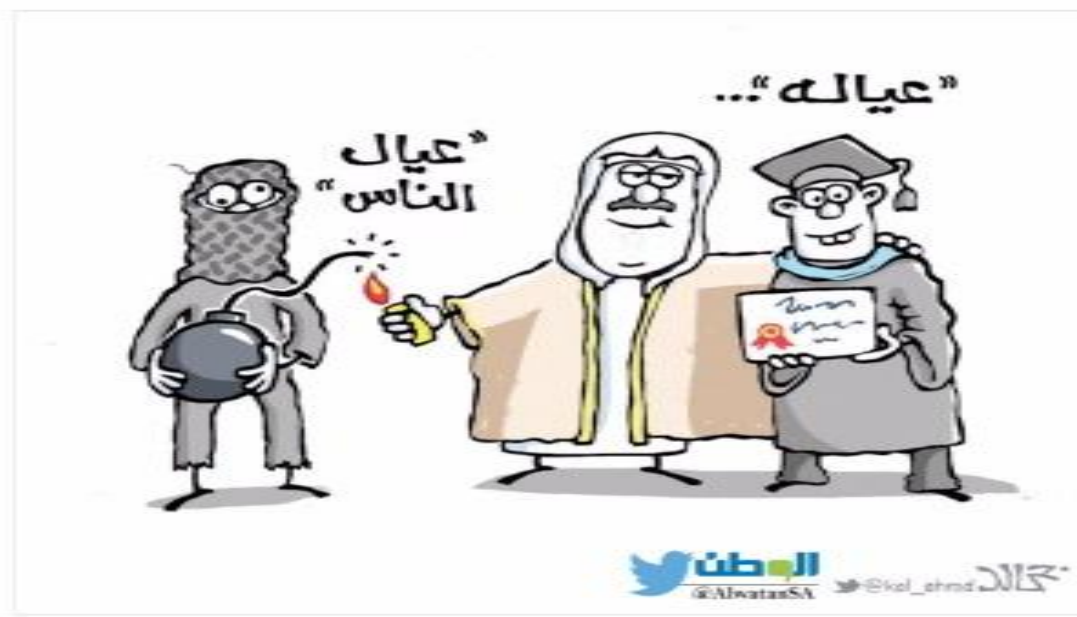

Figure 3: Religious People and Terrorism

(Alwatan Newspaper 2018, Saudi Arabia,)

Terrorism is a shameful deed and is condemned by all religions and societies worldwide. Some religious people play double standards in society. They deceive innocent people and ask them to protect religion and nation by killing civilians (disbelievers so they believe.) They keep luring them to commit suicide bombings in order to get high position in the hereafter. At the same time, they send their kids overseas to study and get certificates.

From the iconic side, the three individuals in the caricature resemble what actually is the case. The individual with visor and carries the bomb is the terrorist. The man with a light in his right hand flaming the bomb is the one who pushes the person to kill people. Simultaneously, his left hand is hugging his son who has a certificate. The fanatic stance (interpretant) of the guy to suicide is the result of the constant attempting from the religious person to do so. Therefore, it is the indexical relation between reason and effect (sign/object). The suspicious stances of some religious people accumulate this view about them in some society (interpretant). This conventional view is symbolic. It might be altered according to the society's trend.

D)

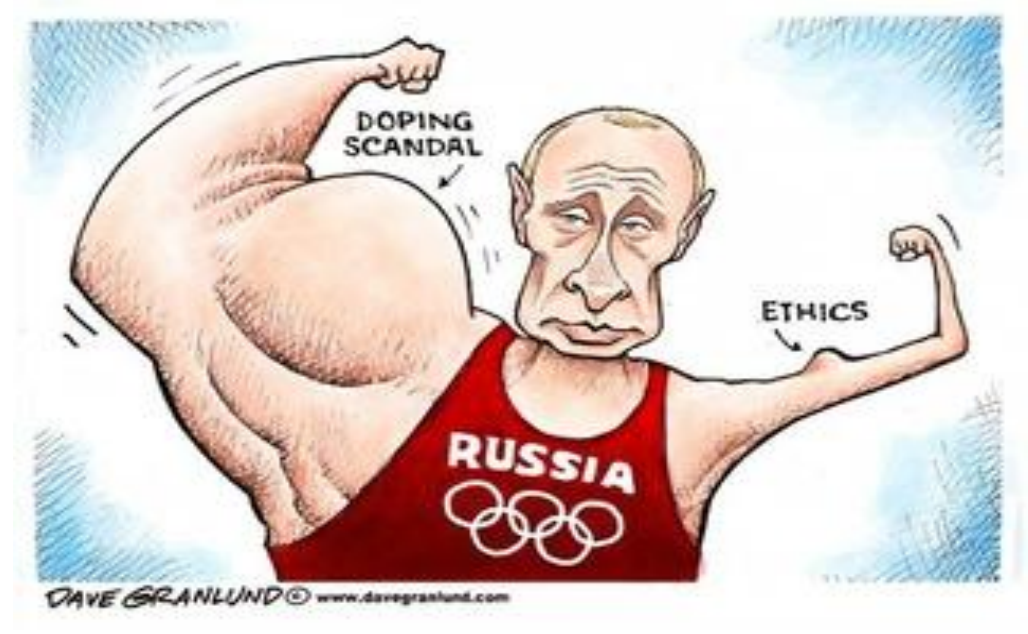

Figure 4: Athletic Doping Scandal in Russian

(Russian Today Newspaper, July 2016, Russian)

The caricature sheds light on the athletic doping scandals committed by some Russian athletes. President Putin was accused of encouraging such deeds.

The face of the Russian president Putin and the logo of the Olympic games he wears (sign) refers to the real objects. The relationship between them is iconic. Russian athletes won many Olympic medals. After blood tests, some positive doping diagnosis (sign) put them in the blacklist. The caricature shows Putin (Russian athletes) is poor ethically and strong with doping (object). The connection between sign and object is index. The common perspective about Russian athletes (interpretant) is passive because of the doping scandal they did. They need to prove the opposite to change people's minds about them.

E) 


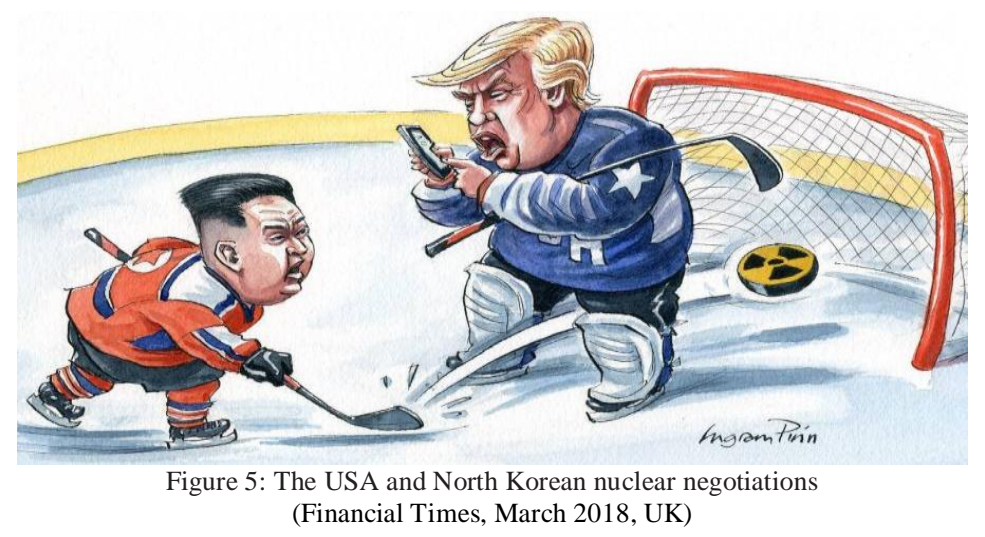

America shoulders the responsibility of North Korea denuclearization. Instead of the longtime dispute between America and North Korea, President Trump prefers negotiation to this issue.

The caricature shows Kim Jong-un, Donald Trump, the match court, and the nuclear weapon as a ball. North Korean's president wins the negotiation because he focuses on his goal while Trump is busy twitting. The relation between some elements of the sign in the caricature and the object they refer to is iconic. To show the indexical relationship, the caricature reflects what happened in negotiation. North Korea triumphed over America. The relation between caricature (sign) and the reality (object) is a correspondence in fact. The people worldwide had the impression before the negotiation that Trump could denuclearize North Korea. However, the view reversed. Nothing happened, but a victory for North Korea (interpretant). This connection between (sign) and object is symbolic.

Stylistically, in the caricatures above, some components surprise readers. They deviate from the socially accepted norms. In caricature 1, there are some foregrounded elements such as, the big hand of the Iranian person that extends to Yemen and the Arab Coalition drone that cut the Iranian's hand. The caricaturist de-familiarizes these elements to enhance the idea of action and reaction in both sides. In Caricature 2, there are unexpected irregularities. The caricaturist personalizes the corrupt government as an obese person and people/citizens as a skinny and semi-naked person. This idiosyncratic style of the caricaturist is foregrounding. In caricature 3, it is known about religious people that they guide people to the right path. However, the abstract foregrounding of religious people in the caricature shows them otherwise. In caricature 4, the extraordinary big and tiny muscles of Russian's president are unexpected irregularity/ deviation to show the contradiction between ethic and doping. In caricature 5, the field of the match, ball (nuclear weapon), bats are all foregrounding elements to represent the negotiation. This style of communication in all caricatures are foregrounding because the caricaturists use idiosyncratic styles to present to the readers the familiar thing in an unfamiliar way in order to support and enhance their perception about the issues raised.

\section{B. Social Caricatures}

As mentioned earlier, caricatures are loaded with political, cultural and social messages. Social ones criticize unwanted social behavior. Hadjadj (2005) divides social caricatures into three categories; pictorial caricatures, gags caricatures, and illustrative caricatures. They are the mirror of society and they tackle contradictions and ills in the community in a satirical way. Therefore, the real connection between caricatures sign and object is iconic. The indexical relation between caricatures sign and object is a correspondence in fact. The traditional/cultural relation between some elements of sign and some elements of the object is symbolic because it shows people's general trend about them. All these trichotomy parts of sign/object connections are noticed in the following social caricatures.

A)

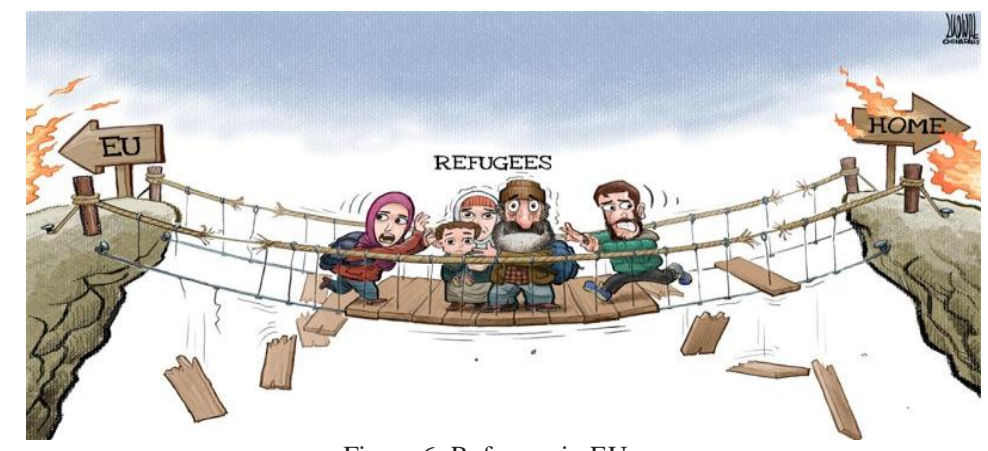

Figure 6: Refugees in EU

(Daily China, January 2016, China)

The refugee's crisis becomes a dilemma all over the world. The natural disasters and civil wars give birth to hundred thousands of homeless people. Their life is at risk in their country and similarly, they are not welcomed by EU countries.

The caricature shows the horrible situation of the refugees. They are suspended on ruined bridge, fire is in their 
homeland and fire is waiting for them in EU countries. Home, refugees, EU, and the ruined bridge are the sign. They refer to the real objects. This relation between some elements of a sign and some elements of an object is iconic because it reflects the reality (interpretant). The caricature also has a correspondence in fact to form an indexical relation between the sign and object. The common views about refugees are that they can't go back home, they currently live in bad and inhuman conditions and they are not welcomed by nations they aim to go (interpretant). This conventional relation between sign and object is symbolic.

B)

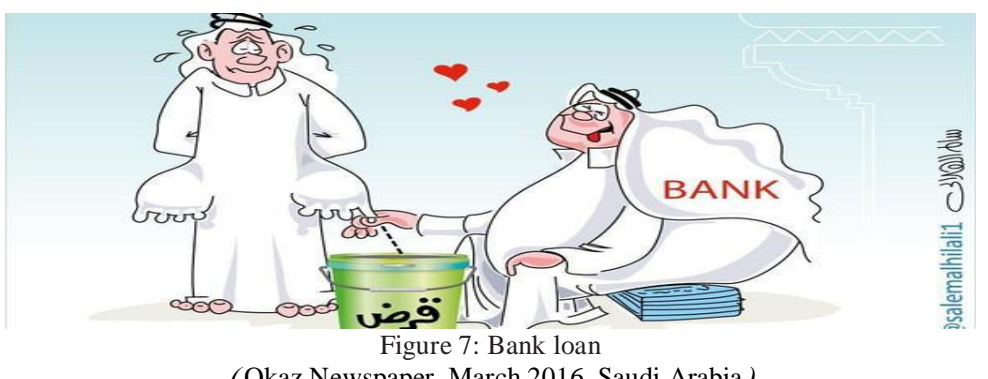

The bank loan is people's nightmare. The three parts of the caricature are; the bank, the borrower and the loan. The bank provides loan for the clients, however, the consequences of that are horrible. It imposes heavy interests on the borrower. He becomes the sustainable income source for the bank for many years.

The fat man represents the bank. The standing man is the borrower and the crock is the loan. The caricaturist writes the word bank and loan to emphasize the iconic relation between them (sign) and the real objects. He also exaggerates in displaying the pockets of the standing man as the cow's teats full of milk (money). The majority of people who are under bank debts complain of the heavy and never-ending interests. This caricature speaks what people suffer from in reality. Therefore, the relation between some sign's elements and some object's elements is indexical, because unless there is complaining, there is no caricature. Culturally and conventionally speaking, those who have bank transactions related to loans always pay high-interest rates (interpretant). This relationship between sign (caricature) and object (people perspective) is symbolic.

C)

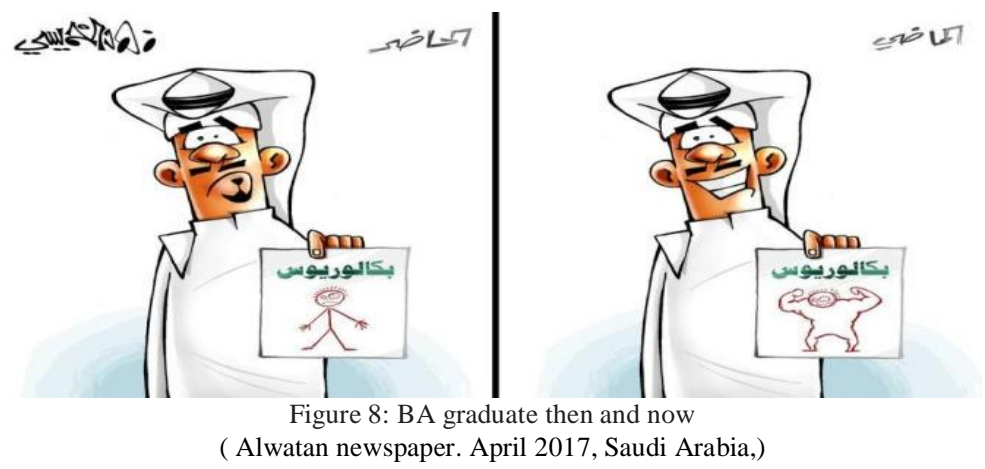

In the past, BA certificate holders had a privileged status in society. The good quality of education, they got, qualified them to get a job easily. However, at present, the situation has changed. Numerous graduates with low quality of education and similarly, few numbers of vacant jobs make the situation of the graduates horrible.

There is an intertwined connection between caricature as a sign and the real object. The right part of it shows a graduate smiling. He would be someone "big" in society. The left part of it refers to the graduate with so many questions in his mind. No jobs are available. So many rivals in the same field apply for a single post. This relation between parts of the sign and parts of the object is iconic. The indexical relation between sign and object can be noticed in the low quality of education nowadays. It resulted in so many graduates with low quality; on the other hand, the good quality in the past resulted in qualified graduates. In the past, the quality of education is far better than the one today. This is the traditional view of society about the graduate then and now. This relationship between signified (sign) and society view (interpretant) is symbolic.

D) 


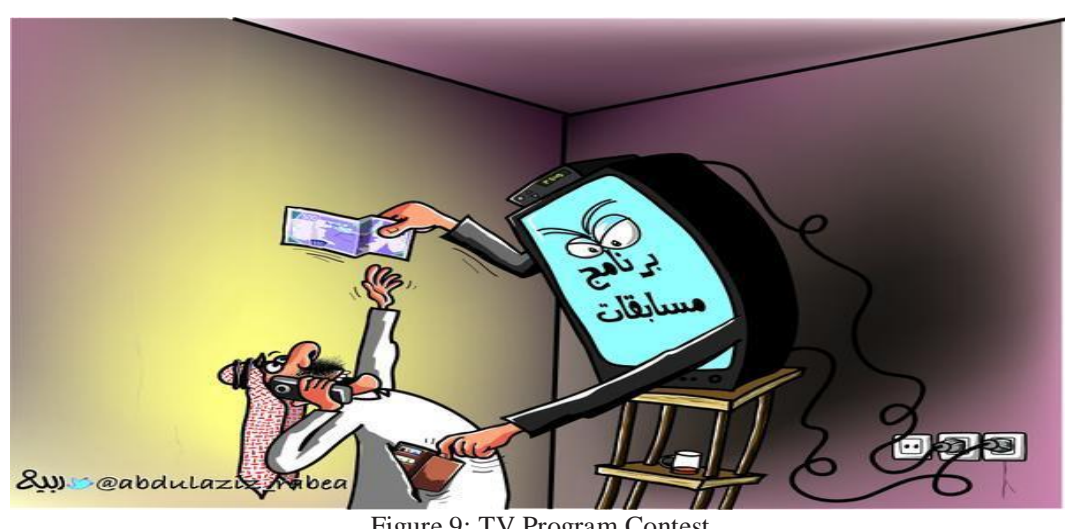

Figure 9: TV Program Contest

(Abu Nawaf network, https://abunawaf.com)

The plethora of contest programs on TV channels becomes the subject matter of people worldwide. The producers' luring techniques drag a huge number of viewers to participate in the contest via phone calls. Usually, the viewer/ participant holds on for a long time waiting for his turn to answer the questions. Of course, holding on for long drains the balance he has. If he wins a prize, though it rarely happens, he will lose double the amount of money on recharging the balance to holding on and waiting for his turn.

The connection between the viewer and the TV program with two hands(sign) and the reality (object) is iconic. On the other hand, the obsession of a person to win the prize and, simultaneously, spend a lot of money on charging his cell phone balance (sign) is the effect of the composer's luring techniques (object) for the person to participate is an indexical relation. People have a common trend that all TV contents programs are fraud. They take much more than what they give (interpretant). This conventional view is symbolic.

Stylistically in the social caricatures discussed above, there are some elements that stand out from the other surrounding ones in each caricature. They are foregrounded. The caricaturists intend to de-familiarize them for the purpose of reinforcing the perception of familiar things. In caricature 1, the caricaturist concretizes and visualizes the psychological and physical suffering of the refugees worldwide. In caricature 2, the people who are under bank debts are the sustainable income interests source for the bank. In caricature 3, the foregrounding elements (at present and past) summarize the statue of the graduates before and at present. In caricature 4, the unexpected irregularity (showing TV program with two hands) is foregrounding because it de-familiarizes the familiar things.

\section{CONCLUSION}

Icon, index, and symbol are the significant issues in sign. The relation between sign and object in them generate further interpretants. This paper focuses on signs beyond verbal communication. The caricatures I analyzed above are likewise. The relationship between sign and object in all caricatures results in one of the three ways (interpretants). First, it is an icon if the relationship is likeness. Second, it is index if it has correspondence in fact. Third, it is a symbol if it is imputed characters. Stylistically, caricaturists use an idiosyncratic style to convey intended ideas. This style is foregrounding because they use unexpected irregularity/deviation via making certain items of the images stand out from others. They also de-familiarize familiar things to shed light on the intended ideas.

\section{APPENDIX}

\begin{tabular}{|c|c|c|c|c|c|c|}
\hline \multicolumn{2}{|c|}{ Caricature } & No & Sign & Object & Interpretant & Foregrounding elements \\
\hline \multirow{7}{*}{$\tilde{\varepsilon}$} & \multirow{5}{*}{ 冚 } & 1 & caricature & Iranian leader & Iranian leader & $\begin{array}{l}\text { Long hand and adorn cuts } \\
\text { the hand }\end{array}$ \\
\hline & & 2 & caricature & Government, people & $\begin{array}{l}\text { Corrupt government } \\
\text { and hungry people }\end{array}$ & $\begin{array}{l}\text { Hungry man feeds wealthy } \\
\text { man. }\end{array}$ \\
\hline & & 3 & caricature & $\begin{array}{l}\text { Religious man, his son, and a } \\
\text { terrorist }\end{array}$ & $\begin{array}{l}\text { Double standard } \\
\text { religious people play } \\
\text { in society }\end{array}$ & $\begin{array}{l}\text { Religious man is Flaming } \\
\text { the bomb in the hand of } \\
\text { others and hugging his } \\
\text { graduate son. }\end{array}$ \\
\hline & & 4 & caricature & Russian's president & $\begin{array}{l}\text { Winning games prizes } \\
\text { and doping scandal }\end{array}$ & $\begin{array}{l}\text { Monster muscle with } \\
\text { doping and tiny one with } \\
\text { ethic. }\end{array}$ \\
\hline & & 5 & caricature & $\begin{array}{l}\text { North Korean and American's } \\
\text { presidents, field of match, cell } \\
\text { phone and unclear weapon }\end{array}$ & $\begin{array}{l}\text { NK president wins the } \\
\text { negotiations }\end{array}$ & $\begin{array}{l}\text { Negotiation is as a ball } \\
\text { match. American lost. }\end{array}$ \\
\hline & \multirow[t]{2}{*}{ 产. } & 1 & caricature & Refugees situation & $\begin{array}{l}\text { Horrible and inhuman } \\
\text { situation of refugees }\end{array}$ & $\begin{array}{l}\text { Fire in both sides, ruined } \\
\text { bridge they stand on }\end{array}$ \\
\hline & & 2 & caricature & Bank, loan and borrower & $\begin{array}{lll}\text { Heavy } & \text { and } & \text { long } \\
\text { interests } & \text { taken } & \text { from } \\
\end{array}$ & $\begin{array}{l}\text { Borrower with cow's teats, } \\
\text { crock (loan), and fat man }\end{array}$ \\
\hline
\end{tabular}




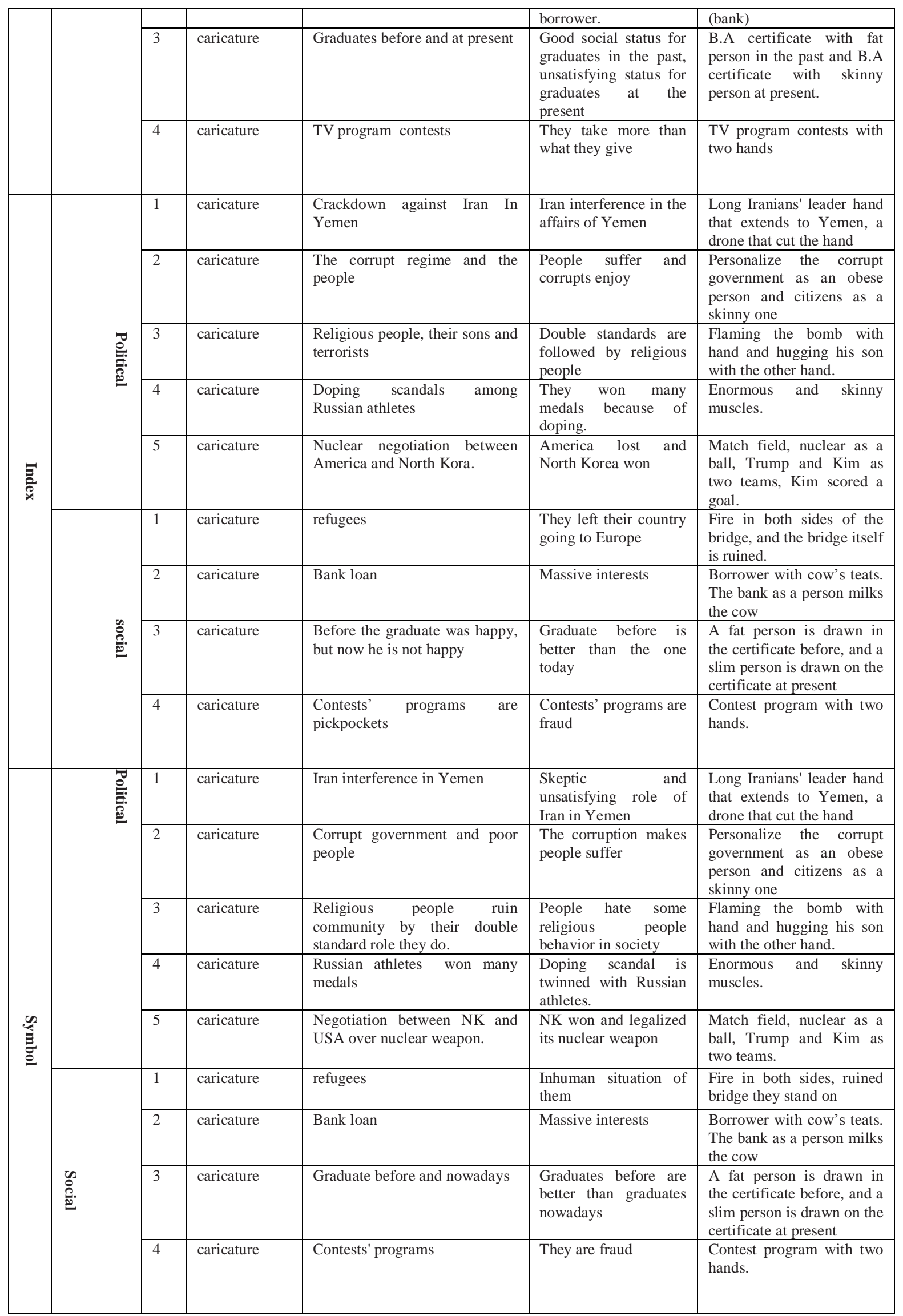




\section{REFERENCES}

[1] Atkin, A. (2005). "Peirce on the Index and Indexical Reference". In Transactions of the Charles S. Peirce Society. 41 (1), $161-$ 188.

[2] Bakhtin, M. (1990). Art and Answerability. Austin: University of Texas.

[3] Barthes, R. (1972). Mythologies. USA, Noonday Press.

[4] Chalániová, D. (2011). "Picturing the EU - Political Cartoons of the European Union in the International Print". 6th ECPR General Conference Reykjavik, 25th - 27th August 2011.

[5] Farias, P. and Queiroz, J. (2003). "On Diagrams for Peirce's 10, 28, and 66 classes of signs". Semiotica. 147 (1/4): $165-184$.

[6] Ferdinand de Saussure. (1959). Course in General Linguistics. New York: McGraw- Hill.

[7] Greenberg, J. (2002). "Framing and Temporality in Political Cartoons: A Critical Analysis of Visual News Discourse". The Canadian Review of Sociology and Anthropology, Vol. 39, No. 2, 181-198

[8] Hadgagi, Y. (2015). “An Investigation of Language Use in Arabic Caricature in Algerian Newspaper”. (M.A thesis). Abu Baker Bulqaed University: Algeria.

[9] Hansen, L. (2011). "Theorizing the Image for Security Studies: Visual securitization and the Muhammad Cartoon Crisis". European Journal of International Relations, Vol. 17, No. 1, 51-74

[10] Lalor, B. (1997). "The Classification of Peirce's Interpretants". Semiotica. 114 (1/2): 31-40.

[11] Leech, G. and Short, M. (2007). Style in Fiction. (2nd ed.) Pearson Education Ltd: UK.

[12] Lynch, J. (1926). A History of Caricature. London: Faber \& Dwyer.

[13] McIntyre, Dan. (2003). "Using Foregrounding Theory as a Teaching Methodology in a Stylistics Course.” Style, vol. 37, no. 1, 2003, pp. 1- 13. JSTOR, JSTOR, www.jstor.org/stable/10.5325/style.37.1.1. 8/1/2019.

[14] Morris, R. (1992). "Cartoons and the Political System: Canada, Quebec, Wales, and England". Canadian Journal of Communication, Vol. 17, No. 2, 253-258

[15] 15- Müller, R. (1940). "On the Principles of Construction and the order of Peirce's Trichotomies of Signs". Transactions of Charles S. Peirce Society. 30 (1), 135153.

[16] Press, C (1981). The Political Cartoon. New Brunswick. NJ: Dicknison University Press.

[17] Sandbrook, D. (2010). The Art of Outrage. New Statesman, 2. august 2010, Vol. 139, No. 5012, 26-31.

[18] Zalta, Edward. N and etal. (eds). (2010). Stanford Encyclopedia of Philosophy: Peirce's Theory of Sign. In, https://plato.stanford.edu/entries/peirce- semiotics/. 20/12/2018.

Hasan Mohammed Saleh Jaashan got his PhD (applied Linguistics) in 2006 form Aligarh Muslim University, India. The specific area of interest is stylistics and discourse analysis

$\mathrm{He}$ is an Associate Professor of applied linguistics in the Department of English, Faculty of Languages and Translation, King Khalid University, Saudi Arabia. In 2011, he taught as a visiting Assistant Professor in the Department of English Literature and Linguistics at Qatar University, Qatar. From 2006 to 2010, he worked in the Department of English, Al-Mahweet Faculty of Education, Sana'a University, Yemen and he chaired the department in the sessions 2009-2010. Throughout his academic career, he almost taught all linguistic and skills courses in BA and some courses in master programs. He also supervised and examined some master dissertations. He has many publications in his area and he participated in many international conferences and symposiu ms. 